\title{
$\begin{array}{llllllll}\boldsymbol{R} & \boldsymbol{a} & \boldsymbol{s} & \boldsymbol{p} & \boldsymbol{r} & \boldsymbol{a} & \boldsymbol{v} & \boldsymbol{e}\end{array}$
}

\section{PRIJEVODI NAPOLEONOVA KATEKIZMA (1806.) U DALMACIJI I ILIRSKIM POKRAJINAMA, 2. DIO}

\author{
Teodora Shek Brnardić
}

Hrvatski institut za povijest, Zagreb tshek@isp.hr
UDK: 322Nap1"1807“"

27-282.4=030.163.42(497.583Dalmacija)“1807“ https://doi.org/10.34075/cs.56.2.1

Izvorni znanstveni rad Rad zaprimljen 8/2020.

\section{Sažetak}

$S$ francuskom upravom $u$ hrvatskim zemljama stupilo je na snagu i francusko državno zakonodavstvo. Između ostaloga, ono je uključivalo i Konkordat između Napoleona i Svete Stolice iz 1801. te Napoleonovu jednostranu zakonsku nadopunu u obliku 77 „Organskih članaka " iz iste godine. Ovi dokumenti učinili su katoličke biskupije u Francuskoj nekom vrstom carskih upravnih tijela pod nadzorom Ministarstua bogoštovlja. Tako je čl. 39 propisao da će u katoličkim crkvama Francuskoga Carstva od tada nadalje moći postojati samo jedna liturgija i samo jedan katekizam. To je bila osnova za sastavljanje jednoga univerzalnoga Katekizma za sve katoličke crkve u Francuskom Carstvu, poznatoga kao Carski katekizam, objavljenoga 1806. godine. Njega su državni organi vlasti uveli bez poturde pape Pija VII. i u njemu je prvi put u povijesti katekizma uz pouku o četvrtoj Božjoj zapovijedi izrijekom bilo spomenuto jedno svjetouno ime, dakako, cara Napoleona I. Generalni providur za Dalmaciju Vincenzo Dandolo prvi je 1807. godine naložio prevođenje Carskoga katekizma na „ilirski“, tj. hrvatski jezik, jer je Dalmacija postala dio Kraljevine Italije. Taj je pokušaj završio fijaskom zbog recenzija koje su ukazivale na nerazumljivost prijevoda među narodom. U Ilirskim pokrajinama osnovanim 1809. godine prijevodi su, bilo cjeloviti, bilo tek nekoliko poglavlja, na poticaj civilnih vlasti objavljeni 1811. i 1812. godine, i to na čak četirijezika: talijanskom, slovenskom, njemačkom i „ilirskom“ jeziku. Premda su ostali bez utjecaja jer su Ilirske pokrajine ukinute 
već 1813. godine, a Napoleonov katekizam strogo zabranjen od strane austrijskih vlasti, ovi prevodilački pothvati ostaju vrlo vrijedan primjer propagande i pokušaja kulturnoga transfera Napoleonova imperijalnoga kulta u ove krajeve, o čemu će biti riječ u ovome radu.

Ključne Riječi: Carski katekizam, napoleonska religija, vjeronauk, kulturni transfer, kulturni imperijalizam

\section{CARSKI KATEKIZAM U ILIRSKIM POKRAJINAMA 1811. - 1812. GODINE}

\subsection{Carski katekizam u školama}

Bečkim mirom 14. listopada 1809. Austrija je morala Francuskoj prepustiti zapadni dio Koruške, Kranjsku, Hrvatsku i Vojnu krajinu jugozapadno od Save, te kraj oko Gorice i Trsta. Njima su pridružene bivše mletačke zemlje Istra i Dalmacija te ukinuta Dubrovačka Republika koje su od 1805., odnosno 1808. bile dio Talijanskog Kraljevstva. Te su godine osnovane Ilirske pokrajine, koje su tehnički bile direktno pripojena Francuskoj. Generalni upravitelj (guverner) Ilirskih pokrajina postao je bivši vojni upravitelj Dalmacije general Auguste Marmont (1774. - 1852.). On je u provedbi reformi imao najviše povjerenja u svoje bivše dalmatinske suradnike s kojima je boravio tri godine u Dalmaciji. Tako je već 23. ožujka 1810. godine za vrhovnog nadzornika javne nastave (l'inspecteur général de l'Instruction publique) u Ljubljani imenovao oca Rafaela Zellija (1772. - 1817.), bivšega profesora Zadarske gimnazije i ravnatelja svih viših škola u Dalmaciji, ${ }^{1}$ koji je Marmonta i privatno poučavao u kemiji. Bartolomeo Benincasa (1746. - 1816.) imenovan je u srpnju 1810. godine generalnim cenzorom za Ilirske pokrajine i kao takav, a i s obzirom na iskustvo u Kraljskom Dalmatinu, preuzima dužnost glavnoga urednika novoga novinskoga glasila Službeni telegraf za Ilirske pokrajine (Télégraphe Officiel des Provinces Illyriennes) (prvi broj izašao 3. listopada 1810.). ${ }^{2}$ Telegraf je trebao izla-

1 Antun Cuvaj, Građa za povijest školstva, sv. 2, Trošak i naklada Kr. hrv.-slav.dalm. zem. vlade, Zagreb, 1910., 397.

2 Na toj dužnosti ostao je samo dva mjeseca, nakon čega ga nasljeđuje urednik Beaumes (ime nepoznato i nedostupno u literaturi). $U$ prosincu iste godine povjerena mu je dužnost i vrhovnoga upravitelja knjižnica Ilirskih pokrajina. Milko Kos, „Télégraphe officiel“ in njegove izdaje, Glasnik Muzejskega društva za Slovenijo, 7-8 (1926. - 27.), 1-4, 5. U Benincasinoj službenoj korespondenciji koja se čuva u Nacionalnoj knjižnici u Ljubljani može se naći dosta podataka o njegovoj potrazi za prevoditeljem „ilirskoga“ izdanja službenih novina, 
ziti na francuskom, talijanskom, njemačkom te na „ilirskom“ jeziku koji će se pokazati najkompliciranijim. ${ }^{3}$

U skladu s Marmontovim programom jezičnoga jedinstva, prvi školski dekret donesen je 4. srpnja, a objavljen je 10. listopada 1810. godine u službenim novinama Télégraphe officiel kao Opći plan javne nastave u pokrajinama (Plan général de l'Instruction publique dans les provinces). Marmont napominje kako „različiti narodi mogu i moraju vidjeti u ovom planu kako se skrbi za opće obrazovanje razmjerno zemljama i društvenim slojevima“. ${ }^{4}$ Prema ovom planu javna se nastava sastoji od pučkih škola (écoles normales, écoles primaires), gimnazija i liceja (čl. 1) i bit će jedinstvena (uniforme) na čitavom prostoru Ilirskih pokrajina (čl. 21). Predmeti u primarnim (pučkim) školama predavat će se na narodnom jeziku (le langue du pays), a u licejima i centralnim školama (liceji u Ljubljani i Zadru) na francuskom i talijanskom, a po potrebi i latinskom jeziku (čl. 22). ${ }^{5}$

U ovom nastavnom planu katekizam je predviđen za nastavu vjeronauka u osnovnim školama i gimnaziji. Naime, čl. 23 izrijekom kaže da će se u primarnim (pučkim) školama učiti čitati i pisati na zemaljskom jeziku (le langue des pays) zajedno s osnovama aritmetike, a predavat će se i „katekizam koji će biti podvrgnut našem odobrenju“. I u gimnazijama se predviđa nastava na narodnom jeziku, elementi francuskoga, talijanskoga i latinskoga jezika, sustav utega i mjera, kao i katekizam (čl. 24). Na licejima je predviđeno uče-

baš kao što je to bio slučaj s Kraljskim Dalmatinom. Nikica Kolumbić i Tatjana Radauš, „Bartolomeo Benincasa“, Hrvatski biografski leksikon, http://hbl.lzmk. hr/clanak.aspx?id=1729 [skinuto 24. rujna 2019.]. U Zbirci rukopisa te rijetkog i starog tiska nalazi se pod sign. Ms 1467 fond Illyrica - arhivalije iz vremena Ilirskih pokrajina] koje sadrže (između ostaloga): korespondenciju Bartolomea Benincase, 1810. - 1811.; korespondenciju Rafaela Zellija, 1810. - 1813.; registre korespondencije uprave Ilirskih pokrajina te Vodnikiana - službeni dopisi, koje je potpisao Valentin Vodnik ili se odnose na njega. Katalog rokopisov Nacionalne in univerzitetne knjižnice $v$ Ljubljani https://www.nuk.uni-lj.si/sites/default/ files/dokumenti/2015/katalog_rokopisov.pdf [skinuto 24. rujna 2019.]. Vodnik je bio prevoditelj slovenske verzije Carskoga katehizma. Više o fondu Illyrica vidi kod Melita Pivec, Ilyrica v. drž. licejski knjižnici v Ljubljani, Glasnik muzejskoga društva za Slovenijo, 7-8 (1926. - 27.) 1-4, 53-54. Nažalost, nisam konzultirala ovu zbirku jer sam podatke o njoj našla tek naknadno.

3 Čl. III „Glavna cenzura će skrbiti o uređivanju službenoga periodičnoga lista koji će donositi vladine akte, političke i druge novosti“. Marmontov cenzurni dekret od 5. veljače 1810. godine. Glavna cenzura ustanovljena je 27. srpnja 1810. godine u Ljubljani. Janko Tavzes, Slovenski preporod pod Francozi. Inavguralna disertacija, s.n., Ljubljana, 1929.,18. Tavzes napominje da je i za izradu njegova doktorata najbogatiji bio fond Illyrica u NUK-u. Isto, 4.

4 Télégraphe officiel, br. 3, 10. listopada 1810., 9.

5 Isto, 10-11. 
nje francuskoga i talijanskoga jezika, kao i latinskoga te elemenata povijesti i zemljopisa, matematike logike, morala i fizike (čl. 25). U pučkoj školi vjeronauk je u nižem odsjeku prvoga razreda sadržavao osnovne pojmove vjeronauka prema odobrenju generalnoga guvernera. U višem odsjeku prvoga razreda i nižem odsjeku drugoga razreda učio se katekizam, a i višem odsjeku drugoga razreda uz katekizam i crtice iz biblijske povijesti. ${ }^{6}$ I u gimnaziji se vjeronauk održavao jedanput tjedno. ${ }^{7}$

Carski katekizam je tako bio svrstan među najtraženije udžbenike na narodnom jeziku za potrebe nastave $u$ primarnim školama i gimnaziji. Iz korespondencije sačuvane u Marmontovu arhivu u francuskom mjestu Châtillon-sur-Seine razvidno je da je za organiziranje prevođenje katekizma bilo zaduženo uredništvo i prevoditelji novina Télégraphe officiel koje je nadgledao Bartolomeo Benincasa. Dakle, slično kao i kod Kraljskoga Dalmatina. U pismu od 1. rujna 1810. godine iz Ljubljane Benincasa obavještava Marmonta da će kasniti izlaženje Télégraphe officiel na četiri jezika, između ostalog i zato što se njegov ured bavi i prevođenjem više početnica i katekizama (livres élémentaires et catéchismes) koje su dogovorili (convenus) nadzornik Zelli i on. ${ }^{8}$ Prevođenje novina s francuskoga na „ilirski jezik“ pokazalo se kompliciranijim od prevođenja na talijanski i njemački jezik: opet je - kao i u dalmatinskome slučaju - iskrsnuo problem najrazumljivijega dijalekta i grafije.

\subsection{Dileme oko „ilirskoga“ jezika}

Marmont je u svrhu racionalnijega upravljanja želio u heterogene Ilirske pokrajine uvesti jezično, upravno, zakonodavno i crkveno jedinstvo. Za razliku od Dandola koji je smatrao da „ilirskom“ narodnom jeziku nije mjesto u školi, Marmont je priznavao njegovu vrijednost. Međutim, na teritoriju Ilirskih pokrajina postojala je veća raznolikost govornika „slaveno-illirskoga“ jezika, tj. slovinskoga u odnosu na Dalmaciju: uz Slovence koji su njegovali svoj (kranjski) jezik i književnost, tu su bili krajiški Hrvati, čija je štokavština bila ikavska i vezana za slavonske tradicije koje su se razlikovale od dal-

$6 \quad$ Andrija Rački, Crkvene reforme francuske vlade u senjsko-modruškoj biskupiji (1809. - 1813.), Bogoslovska smotra, 1 (1910.) 4, 342.

7 Čl. 8 o informaciji i disciplini na karlovačkoj gimnaziji: "Svaki će učitelj jedanput u tjednu učiti u svom razredu katekizam od gubernija odobren." Rački, Crkvene reforme, 342.

8 Frano Baras, Ispisi iz Archives Marmont (Châtillon-sur-Seine), Građa i prilozi za povijest Dalmacije, 17 (2001), 49. 
matinskih. Kao vojvoda od Dubrovnika (Duc de Raguse), Marmont je naglašeno favorizirao dubrovačku (i)jekavštinu, čiju je vrijednost dobro upoznao tijekom boravka u Dubrovniku. Štoviše, pristao je biti pokrovitelj gramatike „ilirskoga“ jezika (Grammatica della lingua illirica, Dubrovnik, 1808.) pijarista Franje Marije Appendinija (1768. - 1837.) te trećega sveska trojezičnoga rječnika Vocabolario italianoillyrico-latino franjevca Joakima Stullija (1730. - 1817.). Dubrovačku je štokavštinu smatrao vjerojatno pod Appendinijevim utjecajem najsavršenijom od „slaveno-ilirskih“ dijalekata ${ }^{9}$, i kao takvu ju je, pored talijanskoga, njemačkoga i francuskoga, htio uvesti kao četvrti službeni jezik i književni jezik za sve slavenske govornike u Pokrajinama, uključujući i Slovence. ${ }^{10}$

Marmont je u proljeće 1810. godine u Ljubljanu čak pozvao dubrovačkog opata Antuna Sivrića (1765. - 1839.). ${ }^{11}$ On je u glavnom stožeru trebao poučavati francuske časnike „ilirskom“ jeziku i preuzeti katedru za „ilirski“ jezik na centralnoj školi (liceju) u Ljubljani. Do toga ipak nije došlo. ${ }^{12}$ Naime, krug slovenskih preporoditelja koji se okupljao oko mecene Sigismunda Zoisa (1747. - 1819.), a koji je uključivao i jezikoslovce Jerneja Kopitara (1780. - 1844.) i Valentina Vodnika (1758. - 1819.), odlučno se suprotstavio ideji da bi slovenski jezik bio podčinjen dubrovačkoj štokavštini. Dokazivali su da je slovenski (još nazivan i „kranjski“) jezik jednako vrijedan i da ima višestoljetnu književnu tradiciju. ${ }^{13} \mathrm{Na}$ kraju je Marmont sa Zellijem odustao od ideje nametanja dubrovačko-ilirske varijante.

Kao što je spomenuto, ured Bartolomea Benincase kao glavnoga cenzora bio je nadležan i za prevođenje i za uređivanje Službe-

9 Marmontovu moguću visoku ocjenu vrijednosti dubrovačke štokavštine moguće je razabrati iz uvoda njemu posvećene Appendinijeve „ilirske“ gramatike; .,,Il dialetto Ragusino è rispetto alla lingua Slavo-Illirica ciò, che fu l'Attico per la Greca, o ciò, che è il Toscano per l'Italiana." Franjo Marija Appendini, Grammatica della lingua illirica, Antonio Martecchini, Dubrovnik, 1808., xxii.

10 Kidrič, Francè: Marmont duc de Raguse, Auguste-Frédéric-Louis Viesse de (1774-1852). Slovenska biografija. Slovenska akademija znanosti in umetnosti, Znanstvenoraziskovalni center SAZU, 2013. https://www.slovenska-biografija. si/oseba/sbi349002/ [skinuto 11. listopada 2019). Izvorna objava u: Slovenski biografski leksikon, 5. sv. Maas - Mrkun. Franc Ksaver Lukman et al., Ljubljana, Zadružna gospodarska banka, 1933., i Drago Roksandić, Vojna Hrvatska/La Croatie militaire. Krajiško društvo u Francuskom Carstvu (1809 - 1813), sv. 2, Stvarnost, Zagreb, 1988., 165.

11 O malo poznatom Sivriću vidi: Marijan Sivrić, Dubrovački opat Antun, ca. Sivrić, pjesnik, prevoditelj i jezikoslovac, Suvremena pitanja, 17 (2014.), 131-145.

12 Frano Baras, Maršal Marmont i hrvatski jezik, Radovi Pedagoške akademije Split, (1977) 2, 70 i Luka Vidmar, Zoisova literarna republika, Založba ZRC, 2010., 272.

13 Isto. 
noga telegrafa te za cenzuru školskih knjiga među koje se ubrajao katekizam. ${ }^{14}$ Benincasa se za prevođenje Telegrafa na „ilirski“ jezik najprije obratio svom starom znancu Dominiku Budroviću pismom od 10. srpnja 1810. godine, međutim od njega nije primio nikakav odgovor, tj. takav nije sačuvan $\mathrm{u}$ Benincasinoj korespondenciji $\mathrm{u}$ Ljubljani. ${ }^{15}$ Nakon toga se iz korespondencije vidi da je Benincasa iz Trsta doveo izvjesnog Dubrovčanina Antona Bertolinija (?) po preporuci napuljskoga konzula Abbatinija i 1. rujna 1810. zaposlio ga kao tajnika-tumača kod sebe pri glavnoj cenzuri te posebno kao prevoditelja na „ilirski“ jezik. Obećava mu nagradu za prevođenje školskih knjiga. ${ }^{16}$ Zanimljivo je to da mu Benincasa u jednom pismu čestita na učinkovitosti, tj. da je preveo na „ilirski“ jezik pored tekućih stvari „katekizme, gramatiku i aritmetiku“. Međutim, nakon Bertolinijeva odlaska u Rijeku za profesora francuskog jezika Benincasa mu piše 1. prosinca 1810. da su se pojavila „različita mišljenja vezano za izbor jezika koji bi se uvažili za prevođenje bilo Telegrafa, bilo nastavnih knjiga, kao i vezano za čistoću njegovih ilirskih tekstova“. Zato mu brzo poručuje da se prestane truditi prevoditi knjige koje je uzeo k sebi i neka se bavi samo poučavanjem francuskoga jezika, u čemu se vladi jako žuri. Da je to mišljenje vrhovnoga nadzornika Zellija. Još mu poručuje neka vrati gramatiku i rukopis bez troškova, te da mu se u tom pogledu ne žuri. ${ }^{17}$ Tako je negativna recenzija jezične čistoće Bertolinijevih tekstova, kao i u Budrovićevu slučaju prije, presudila prekidu suradnje.

Prema Tavzesu, iz okružnice glavnoga vladinoga tajništva od 8 . prosinca 1810. godine koja je poslana svim intendantima razvidno je da su u Ljubljanu zvali novoga prevoditelja „,ilirskoga“ jezika. ${ }^{18} \mathrm{Zbog}$ potreba vojske potraga je išla u smjeru unutrašnjosti, tj. u Vojnu Hrvatsku, područje nekadašnje Vojne krajine, iz koje je potjecao veli-

14 Ovaj ured davao je tzv. imprimatur („neka se tiska“), odobrenje za tiskanje katekizama, što je prije bilo isključiva domena ureda Katoličke Crkve. Vidi korespondenciju kanonika Isaca de Vallesa s Rafaelom Zellijem. Arhiv Slovenije, Ljubljana, sign. SI AS 27 (Glavni intendant Ilirskih provinc 1809. - 13.), fasc. 72, br. 71, 487 i 394.

15 Tavzes, Slovenski preporod, 21.

16 Isto, 21-22. Tavzes prepričava cijelu kronologiju Benincasine potrage za prevoditeljima i tiskarima Službenoga telegrafa i školskih knjiga.

17 Isto, 24. Iz pisma od 8. siječnja 1811. vidi se da je Zelli vratio Bertoliniju sve njegove rukopise i da o njihovoj vrijednosti nema nikakva pojma jer da ne razumije jezik. Čini se da ih je na prosudbu čistoće poslao ravnatelju dubrovačke škole, što može biti jedino Appendini. Isto. O Bertoliniju se ništa ne zna.

18 Isto. 
ki broj vojnika za carsku vojsku. ${ }^{19}$ Izbor francuskih generala pao je na „nekadašnjega upravitelja [župe] iz Gospića“ (l'ancien administrateur de Gospich), ${ }^{20}$ koji može biti jedino tada 26-godišnji Šime Starčević (1784. - 1859.). On je prema legendi u susretu s Marmontom u Gospiću krajem svibnju 1810. godine dokazao poznavanje francuskoga jezika koje je među širim stanovništvom bilo gotovo posve nepoznato ${ }^{21}$, ali je poput Slovenaca jednako bio protiv nametanja dubrovačkoga dijalekta kao najrazumljivijeg. Njemu kao govorniku ikavske štokavštine utemeljene na narodnom jeziku Like nikako nije odgovaralo nametanje dubrovačko-dalmatinsko-štokavskih dijalektalnih varijanti i talijanske grafije u pisanju, što i opširno obrazlaže u svojoj gramatici. Starčević je bio pozvan u Ljubljanu i ondje je napravio probni prijevod Službenoga telegrafa od 2. siječnja 1811. na „ilirski“ jezik. Isti je poslan na recenziju u Karlovac koju je organizirao sposobni nadzornik hrvatskih pukovnija general Alexis Joseph Delzons (1775. - 1812.). On u svom izvještaju Marmontu od 24. siječnja 1811. navodi da je prijevod pregledalo više osoba, uključujući i „redovnike iz samostana“ (les moines du couvent), tj. franjevaca, i da je prijevod ocijenjen kao dobar, ,,da je ,ilirski' vrlo čist, a pravopis vrlo uredan; riječju, on je prihvatljiv za sve Ilire u ovim krajevima“. ${ }^{22} \mathrm{U}$ pismu spominje da bi dubrovački prijevod bio manje

19 Šime Starčević, kojeg su angažirale francuske vlasti, posvećuje svoju gramatiku „ilirskoga“, tj. hrvatskoga jezika, „vojnicskoj mladosti krajicsnoj“, a „ilirski“ prijevod francusko-njemačke gramatike opata Mosina Französische Sprachlehre „na potribovanje vojnicske mladosti iliricskih darxavah“. Vidi naslovnice u Šime Starčević, Nova ricsoslovnica iliricsko-francezka, Gaspar Weis, Trst, 1812., i Nova ricsoslovnica iliricska, Gaspar Weis, Trst, 1812. U Karlovcu je 1810. otvorena specijalna vojna škola za pouku iz drila i manevriranja francuske vojske (Ecole spéciale d'instruction de l'exercice et de manoevres de l'armé française) za 36 pitomaca, iz svake pukovnije po šest, a iz svake satnije po dva dočasnika. U školi su se osim predmeta iz vojnih znanosti poučavali najprije francuski, latinski i talijanski jezik. Godine 1811. ukinuto je poučavanje latinskoga i talijanskoga jezika. Ivan Devčić, Hrvati i Hrvatska pod Napoleonom Velikim, L. Hartman, Zagreb, s.a., 21.

20 Pismo generala Alexisa Josepha Delzonsa Jardetu (ime na pismu) od 11. prosinca 1810. iz Karlovca. Arhiv Slovenije, Ljubljana, sign. SI AS 27 (Glavni intendant Ilirskih provinc 1809. - 13.), fasc. 73, br. 737. Za tjedan dana Starčević je bio pozvan u Ljubljanu. Pismo Tajništva vlade u Ljubljani biskupu Ivanu Krstitelju Ježiću od 16. prosinca 1810. koje se čuva u Biskupijskom arhivu u Senju. Citirano kod: Ćosić, Šime Starčević, 24.

21 „Francuski je jezik bio, ako se izuzme nekoliko aristokratskih obitelji, gotovo posve nepoznat, a francuski način života temeljito različit od našega, pa se tako našlo samo veoma malo dodirnih točaka." Imbro Tkalac, Uspomene iz Hrvatske, Matica hrvatska, Zagreb, 1945., 36.

22 Pismo generala Delzonsa od 24. siječnja 1811. iz Karlovca. Arhiv Slovenije, Ljubljana, sign. SI AS 27 (Glavni intendant Ilirskih provinc 1809. - 13.), fasc. 73 , br. 704 . 
uspješan u tom podneblju jer da se radi o drugom narječju, koje je iskvareno talijanskim riječima koje se tamo ne bi mogle razumjeti. Ali ipak traži da mu se pošalje i taj prijevod, koji će dati pregledati te će poslati primjedbe. ${ }^{23}$ Dubrovačka verzija ostala je nepoznata (možda se radi o Bertolinijevoj inačici koja mu je bila vraćena), a s obzirom da je probno otisnut Starčevićev prijevod ${ }^{24}$, čini se da je on bio izbor. Ipak, do daljnjeg tiskanja Telegrafa na „ilirskom“ jeziku nije došlo, kao što znamo, a Starčević je prionuo na pisanje svojih dviju gramatika koje je završio do kraja godine. Carski katekizam trebao je prevesti netko drugi.

\subsection{Prevođenje katekizma u Ilirskim pokrajinama}

Katekizmi su bili pripremani tijekom cijele 1811. godinu, a njihovo tiskanje posebno je bilo požureno nakon Napoleonova dekreta o uređenju Ilirskih pokrajina od 15. travnja 1811. godine. ${ }^{25} \mathrm{Iz}$ korespondencije ravnatelja tršćanske gimnazije kanonika Isaca de Vallesa $^{26}$ (?) s vrhovnim nadzornikom školstva Zellijem može se rekonstruirati tijek tiskanja posebnih izdanja Carskoga katekizma za Ilirske pokrajine na talijanskom i slovenskom („kranjskom“) jezi$\mathrm{ku}$. U pismu od 30. travnja 1811. godina de Valles iz Trsta obavještava Zellija da tiskar (Gašpar) Weis namjerava otisnuti, odnosno napraviti pretisak milanske verzije Carskoga katekizma (le catechisme de Milan), tj. Catechismo ad uso del Regno d'Italia, koji je tiskan u Milanu 1807., jer da je za to dobio imprimatur od glavnoga cenzora, tj. Benincase. Međutim, de Valles naglašava da je njemu poznato kako Zelli za tiskanje ima u rukopisu pripremljenu verziju katekizma „za uporabu Ilirskih pokrajina“ (pour l'usage de ces provinces).

23 Isto.

24 Kopiju probnoga otiska Telegrafa sluxbenicskog pronašao je Vjekoslav Ćosić u Državnom arhivu u Zadru (Knjižnica, 880 R-5). Original se čuva u Muzeju grada Trogira. Ćosić, Šime Starčević, 59.

25 Njime je teritorij Pokrajina podijeljen na šest civilnih pokrajina (Kranjska, Koruška, Istra, Civilna Hrvatska, Dalmacija, Pokrajina Dubrovnik) i jednu vojnu pokrajinu, tj. Vojnu Hrvatsku. Glavni su gradovi bili Ljubljana, Villach, Trst, Karlovac, Zadar i Dubrovnik. Njima su upravljali civilni intendanti, a vojni intendant zadužen za Vojnu Hrvatsku, tj. za teritorij krajiških pukovnija, imao je sjedište također u Karlovcu. Décret sur l'organisation de l'Ilyrie, De l'imprimerie du gouvernement, Ljubljana, 1811., 14-13, 19.

26 Isac de Valles (u korespondenciji potpisan kao „kanonik (chanoine) Isac des Wolles“) bio je francuski kanonik iz Avignona koji je kao emigrant boravio dugi niz godina u Trstu. Giuseppe Mainati, Croniche ossia memorie storiche sacroprofane di Trieste. sv. 5, Picotti, Venecija, 1818., 55. Predavao je na gimnaziji francuski jezik. 
Osjeća se pozvanim upozoriti tiskara da odgodi svoj posao do Zellijeva odgovora u kojem bi se izjasnio namjerava li i dalje otisnuti taj rukopis. ${ }^{27} \mathrm{U}$ roku od tri tjedna, tj. 23. svibnja, de Valles potvrđuje primitak „vjerskoga, građanskoga i agrarnoga“ katekizma (catéchisme religieux civil et rural), koji ce odmah proslijediti tiskaru Weisu. ${ }^{28}$

Nakon primitka rukopisa adaptiranoga katekizma Weis je de Vallesu uputio zanimljivo pitanje o mogućnosti tiskanja njemačkoga i „kranjskoga“, tj. slovenskoga, kao i francuskoga prijevoda, iz čega je vidljivo da je talijanska verzija otisnuta prva. De Valles mu je na to odgovorio s nekoliko primjedbi, o kojima piše Zelliju u pismu od 27. svibnja: 1) njemački prijevod mu se ne čini nužnim jer da su „knjige ovoga žanra“ prilično brojne u gradu (vjerojatno Trstu); 2) „kranjski“, tj. slovenski jezik mu se čini krajnje nužan jer da u čitavom okrugu djeca kao i ostali stanovnici općenito ne razumiju još ništa talijanski, pa da bi trebalo prevesti neke katekizme, ali ne sve (znači ne sva tri!); 3) što se tiče francuskog jezika, de Valles iznosi mišljenje da ne bi bilo loše prevesti barem građanski i poljodjelski katekizam radi vježbe mladih početnika u srednjim školama jer da im je knjiga Petit guide des amateurs de l'histoire universelle koja se trenutno koristi ipak preteška. ${ }^{29}$

Srećom, adaptirani primjerci na talijanskom i „kranjskom“ jeziku sačuvani su, pa se može vidjeti njihova originalna struktura. Katekizam nosi naslov Katekizam (ili Kršćanski nauk, što je bilo uobičajenije $\mathrm{u}$ to doba) za uporabu u Ilirskim pokrajinama, uzet iz Katekizma za sve crkve Francuskoga carstva (talijanski Catechismo ad uso delle Provincie Illiriche estratto dal Catechismo di tutte le chiese dell'Impero Francese, 181 1., i „kranjski“ tj. slovenski Kershanski navuk sa ilirske deshele vset is Katechisma sa vse zerkve franzoskiga zesarstva, 1811. i 1812.). ${ }^{30}$ Njegova struktura je trodijelna i

27 Pismo Isaca de Vallesa Rafaelu Zelliju od 30. travnja 1811, sign. SI AS 27, fasc. 72 , br. $71,487$.

28 Pismo Isaca de Vallesa Rafaelu Zelliju od 23. travnja 1811, sign. SI AS 27, fasc. 72 , br. $71,473$.

29 Pismo Isaca de Vallesa Rafaelu Zelliju od 27. svibnja 1811, sign. SI AS 27, fasc. 72 , br. $71,476$.

30 Fran Ilešić, slovenski povjesničar književnosti, pomnom je analizom dvaju originalnih izdanja Carskoga katekizma na talijanskom jeziku u ljubljanskoj Nacionalnoj i sveučilišnoj knjižnici (NUK) detektirao predložak koji je najvjerojatnije poslužio za adaptaciju talijanske i slovenske verzije katekizma za Ilirske pokrajine jer je sav iskrižan i ima bilješke. Fran Ilešić, Slovenski pjesnik Valentin Vodnik i Napoleonov katekizam, u: Mihovil Abramić i Viktor Hoffiller (ur.), Bulićev zbornik. Naučni prilozi posvećeni Franu Buliću prigodom LXXV. godišnjice njegova života od učenika i prijatelja IV. oktobra MCMXXI., Narodne novine, Zagreb, 1924., 625-632. Naime, original je možda koristio sam načelnik javne nastave Zelli, čija 
ne sadržava samo izvatke iz originalne verzije Carskoga katekizma, kako stoji u naslovu, već i dodatke u obliku građanskoga (civilnoga) katekizma (catechismo civile) i poljodjelskoga (agrarnoga) katekizma (catechismo agrario). ${ }^{31}$ Građanski katekizam, sadržajno sličan Dandolovu „nauku ćudorednom,“ sadržavao je „kratku pouku o dužnostima svakoga čovjeka prema sebi sličnima, svojoj obitelji, svojoj domovini, svojoj državi“. ${ }^{32}$ Poljodjelski katekizam bio je definiran kao „kratka pouka o dužnostima čovjeka koji mora obrađivati polje“, a sadržajno je obuhvaćao deset članaka o različitim aspektima obrade zemlje. ${ }^{33}$ Katekizmi napominju da su i građanska zajednica i poljodjelstvo djelo Božje i da ljudi moraju prihvatiti svoje dužnosti jer im one dolaze od Boga. Na pragmatičan način sastavljač katekizma, po svoj prilici načelnik javne nastave Rafaele Zelli sa suradnicima, uspio je ujednačiti udžbeničku produkciju za školsku nastavu u vrlo kratkom roku.

S druge strane, čini se da su karlovački prijevodi na njemački i „ilirski“ jezik, čija se kronologija nažalost ne može rekonstruirati iz neke korespondencije ili arhivskih spisa, išli drugim tijekom. Usporedbom tekstova može se primijetiti da se za prevođenje nisu koristili spomenuti adaptirani prijevodi namijenjeni Ilirskim pokrajinama. Karlovačka je, naime, njemačka verzija doslovni pretisak originalnoga njemačkog prijevoda iz 1807. godine, koji nosi isti naslov, Katechismus zum Gebrauche in allen Kirchen des französichen Kaiserreichs (Kunst- und Industrie-Comtoir, Amsterdam, 1807.). ${ }^{34}$ Razlika je jedino u slovotisku: naime, karlovačka državna tiskara, koju su osnovali Francuzi, nije koristila frakturu, tj. slova njemačke gotice, već latinska slova, jer je vjerojatno njih jedino imala. Kako je njemačka verzija prethodila „ilirskoj“, vjerojatno se njemački original koristio za probni prijevod. Po svemu sudeći, probnu verziju preveo je i

se korespondencija zajedno s ostavštinom Valentina Vodnika, koji je bio glavni prevoditelj slovenskoga katekizma i udžbenika, nalazi u NUK-u. S druge strane, Benincasa je kao glavni cenzor bio nadležan za „čistoću“ izdanih knjiga, pa je i on mogao sudjelovati u adaptiranju. Najmanje je vjerojatno da je Vodnik sam radio ispravke $u$ sadržaju jer za to jednostavno nije bio ovlašten.

$31 \quad$ Njihovo se porijeklo za sada ne da odgonetnuti.

32 Catechismo civile ad uso delle provincie illiriche estratto dal Catechismo dell'impero francese, Stamperia di Gasparo Weis, Trst, 1811., 3. Katekizam se sastoji od uvoda, čl. I „O dužnostima prema sebi“; čl. II. „O dužnostima prema drugima“; čl. III. „O posebnim dužnostima“; IV. „O dužnostima pristojnosti (civiltà).“

33 Catechismo agrario ad uso delle provincie illiriche estratto dal Catechismo dell'impero francese, stamperia di Gasparo Weis, Trst, 1811. Katekizam se sastoji od deset poglavlja posvećenih poljodjelstvu i stočarstvu.

34 Identičnost teksta utvrđena je usporedbom. Originalna njemačka verzija dostupna je na Google Booksu. 
neki franjevac ${ }^{35}$ iz karlovačkoga samostana jer se katekizam moglo prevoditi i s drugih jezika, a ne samo s francuskoga. Uostalom, i prijevod naslova Katechismus upućuje na njemački predložak jer je Katechismus njemačka riječ, ${ }^{36}$ a karlovački profesori poznavali su pretežno latinski i njemački jezik te na njima predavali. ${ }^{37}$ Što se tiče nagađanja da je Starčević autor prijevoda, treba reći da bez obzira na slavonsku grafiju u „ilirskom“ katekizmu nisu prisutna grafijska rješenja koja su karakteristična za Starčevića (npr. $/ l j /=1 j$, a /nj/=nj), a postoje i znatne razlike $u$ pisanju pojedinih riječi, što odaje dvije autorske ruke. ${ }^{38} \mathrm{Za}$ razliku od katekizma, Starčevićeva grafija je na prvi pogled prepoznatljiva u probnom prijevodu i otisku Službenoga telegrafa, pa se oni mogu njemu pripisati, što s katekizmom nije slučaj. Ovaj probni otisak vojne vlasti u Karlovcu dale su, kao što smo vidjeli, na recenziju upravo karlovačkim franjevcima, što mnogo govori o njihovoj reputaciji u sferi "ilirskoga“ jezika.

35 Rački navodi karlovačkoga gvardijana i ravnatelja liceja Ivana Hrizostoma Fogha (1777. - 1834.) kao pristašu Francuza. Rački, Crkvene reforme, 349. Na karlovačkoj gimnaziji i liceju predavali su, osim u nastavi francuskoga jezika, isključivo franjevci. Vidi Cuvaj, Građa za školstvo, 415. Franjevci su imali svoju bogosloviju u Karlovcu i pozamašno iskustvo u bavljenju književnošću, gramatičkim pitanjima i katekizmima. Na području Vojne Krajine franjevci su pretežno bili vojni kapelani koji su pratili vojsku i kao takvi dobro poznavali jezik vojnika. Franjo Emanuel Hoško, Slavonska franjevačka učilišta, Kršćanska sadašnjost, Zagreb, 2011.

36 Također i stavljanje glagolskoga pridjeva trpnoga „uselan“ na kraj naslova Katechismus $u$ svih Francuskog cesarstva cirkvah uselan, što je njemačka konstrukcija u kojoj particip perfekta ide na kraj. U hrvatskom jeziku bilo bi prirodnije da je što bliže subjektu na početku, što se vidi kod Starčevića.

37 Franjo Jurjević, rektor karlovačkoga liceja (više gimnazije) u Karlovcu, izvještava načelnika javne nastave Zellija da, iako su dekretom o školstvu kao nastavni jezici bili propisani francuski i talijanski, to u Karlovcu nije bilo moguće provesti jer profesori te jezike nisu znali, za razliku od latinskoga i njemačkoga jezika, na kojima su najvjerojatnije i nastavili predavati. Decrets, arrêtes, réglements, etc. Rukopisna zbirka Illyrica. Nacionalna i sveučilišna knjižnica u Ljubljani. Citirano kod: Marija Vrbetić, 400 godina karlovačkog školstva, SIZ društvene brige o djeci, Karlovac, 1979., 30.

38 Npr. u Katechismusu (dalje K) piše se „illiti“ (11), a u Starčevićevoj Novoj ricsoslovici iliricsko-francezkoj (dalje N) „iliti“ (280); „koi“ (K, 11) : „koji“ (N,28); „liubav“ (K,5) : „ljubav“ (N,30); „uputchenie“ $(\mathrm{K}, 5)$ : „uputjenje“ (N, 178); „sueti“ $(\mathrm{K}, 5)$ : „sveto “ (N,66); „niegovu“ (K,5) : „njegov“ (N, 113); „Volia“ (K,5) : „volja“ (N, 176); „chovik“ (K,5) : „csovik“ (N,5); „orsag“ (K, 9): „darxava“ (N, naslov); „cirkvah (K, naslov) : „carkva“ (N, 35); „Z- plus instrumental: Z-sudom, Z-Druxtvom, Z-njim $(\mathrm{K}, 7)$ : s' plus instrumental: s'opakim, s'onim, s'mojim (N, 14, 253, 173); itd. Razlike su više nego očite. 
U Tršćanskoj i Ljubljanskoj biskupiji Katekizam je uveden ${ }^{39}$ 1811. godine uz prethodno odobrenje ljubljanskoga biskupa Antona Kavčiča (1743. - 1814., biskup od 1807.) (Tršćanska biskupija bila je ispražnjena). ${ }^{40}$ Vjerojatno zbog biskupove suradljivosti sa Zellijevim uredom za javnu nastavu, talijanski adaptirani original i slovenski prijevodi iz pera predanoga Valentina Vodnika bili su potpuni i uvedeni u nastavu odmah po izlaženju, te su doživjeli čak dva izdanja. ${ }^{41}$

S druge strane, Karlovac, u kojem su bili tiskani probni otisci njemačke i „ilirske“ verzije Carskoga katekizma, bio je još uvijek dio Zagrebačke nadbiskupije s desne strane Save (Transsavanum) koja je bila pod duhovnom jurisdikcijom biskupa Maksimilijana Vrhovca (1752. - 1827.), tvrdoga protivnika Francuza. Ovaj je teritorij Vrhovac uporno odbijao predati bez papinskog odobrenja najprije na upravljanje ljubljanskome biskupu Kavčiču, što je zahtijevao

39 Vicko Kapitanović, Hrvatska crkva pod francuskom vlašću, Croatia christiana periodica 18 (1994.) 33, 152.

40 Anton Kavčić potvrdio je u Vodnikovom slovenskom prijevodu izrijekom nauk ovoga katekizma još 2. rujna 1810: “Ta kershanski navuk je prezhastiti lublanski shkof po imenu ANTON v'sboru svolenih duhovnih pregledal, popravil in poterdil, 2. Dan kimovza 1810." Kershanski navuk, 99. U talijanskoj verziji nije navedeno nikakvo odobrenje. Ovaj podatak bi ukazivao na to da je slovenski prijevod bio napravljen još u jesen 1810. godine osim ako Vodnik nije preveo odobrenje s talijanskog jezika, što je nažalost izostavljeno u tršćanskom izdanju. Tiskanje je uslijedilo tek kada se našla privatna tiskara jer državna nije imala novca. Kopitar 10. kolovoza 1811. u pismu Josefu Dobrovskom spominje da je primio Vodnikov Kershanski navuk. Dana 21. kolovoza zahvaljuje Sigmundu Zoisu na pošiljci Vodnikovih knjiga i pohvaljuje tečnost jezika Kershanskog navuka. Ivan Prijatelj, Slovenci pod Napoleonom, Veda 1 (1911.) 5, 435. Vodnikov prijevod išao je, dakle, u tisak u ljeto 1811. godine. O Kavčiču vidi Francé Kidrič, Dobrouský in slovenski preporod njegove dobe, Tiskajo J. Blasnika Nasl. Univerzitetna tiskarna, Ljubljana, 1930., 190, bilj. 51 i Lisac, Ljubomir Andrej: Kavčič, Anton (1743 - 1814). Slovenska biografija. Slovenska akademija znanosti in umetnosti, Znanstvenoraziskovalni center SAZU, 2013. https://www.slovenska-biografija. si/oseba/sbi1013710/ [skinuto 11. listopada 2019]. Izvorna objava u: Primorski slovenski biografski leksikon, sv. 8. snopič Kacin - Križnar, 2. knjiga. Ur. Martin Jevnikar Gorica, Goriška Mohorjeva družba, 1982.

41 I inače je, prema subjektivnoj ocjeni samoga Marmonta, francuska uprava u pokrajini Kranjskoj bila odlično prihvaćena, i među plemstvom, a i među profesorskom elitom. "U pokrajini Kranjskoj živi mnogo drevnog i vrlo ponosnog plemstva. [...]. Ukratko, nijedna zemlja pripojena Francuskoj nije nam brže i dosljednije postala naklonjenom, usprkos tradicionalno naglašenoj naklonosti koju su njeni stanovnici s pravom pokazivali austrijskom dvoru." Maršal Marmont, Memoari, Frano Baras (prev. i prir.), Logos, Split, 1984., 213. "Ljubljanski licej bio je u rukama odličnih i sposobnih ljudi. Nastojao sam što više unaprijediti obuku koja se tamo davala. Dodijelim im botanički vrt neka posluži za obrazovanje učenika." Isto, 215. 
Marmont, ${ }^{42}$ a onda nakon Dekreta o uređenju Ilirskih pokrajina u travnju 1811. godine Senjsko-modruškoj biskupiji na čelu s frankofilskim biskupom Ivanom Krstiteljem Ježićem (1746. - 1833., biskup od 1789.). ${ }^{43}$ Ježić je $u$ ime francuskih vlasti inzistirao na predaji teritorija na upravljanje, ${ }^{44}$ a prepirka i pregovaranje trajali su sve do 20. siječnja 1813. godine. Tada je Vrhovac predao Ježiću kao svom generalnom vikaru privremenu jurisdikciju nad prekosavskim dijelom biskupije, i to tek poslije naredbe cara Franje I. od 27. studenoga 1812. godine. Ježić je prekosavskom kleru najavio vizitaciju u svibnju iste godine, no nakon otkazivanja do nje nikada nije došlo. ${ }^{45}$ Sredinom kolovoza, nakon provale austrijskih trupa, Francuzi su se povukli iz Karlovca, a do kraja godine i iz ostalog dijela Ilirskih pokrajina, pa se može zaključiti da Carski katekizam nije imao prilike zaživjeti na području hrvatske Ilirije.

Netko je tekst katekizama ipak trebao odobriti s duhovne strane. Ljubljanski biskup Anton Kavčič izrijekom je odobrio tekst slovenskog katekizma, dok je prijevode na području Civilne i Vojne Hrvatske po svoj prilici odobrio senjski biskup Ivan Krstitelj Ježić. Zbog zasluga u suradnji s francuskim vlastima njih su obojica 28. travnja 1813. godine dobili ordene Legije časti. ${ }^{46}$ Obojica su također bili na glasu da su pohlepni na novac za svoj kler i nije im smetalo da vladar odobrava katekizam, odnosno da to bude čin vlade. Ipak, čini se da na zalazu Carstva i u doba ratnih kriza francuska uprava nije strogo inzistirala na uvođenju propisanoga katekizma. U Dubrovniku je, naime, za francuske uprave 1811. godine bilo tiskano drugo izdanje Bellarminova katekizma Nauk kršćanski složen po naredbi s. oca pape Klementa VIII. od kardenala Bellarmina $i$ kratko vježbanje o prvoj ispovjesti $i$ pričešćenju djece nedorasle složeno po naredbi Benedikta XIII., a sve slovinski istomačeno po ocu Innocencu Grgiću Malobračaninu, koji je za područje Dubrovačke nadbiskupije i Stonske biskupije odobrio za tiskanje tadašnji vremešni dubrovački nadbiskup Nikola Bani (1736. - 1815., nadbiskup od 1800.).

42 Rački, Crkvene reforme, 348.

43 U svome dnevniku za 15. siječnja 1813. godine Vrhovac navodi: „Podarhiđakon i dubrovački župnik Hanžić pripovijeda kako senjski biskup požuruje predaju dijela zagrebačke biskupije preko Save. Dobri Bože! Kako to može tražiti jedan katolički biskup!“ Maksimilijan Vrhovac, Dnevnik/Diarium, sv. 2, Metod Hrg i Josip Kolanović (prev.), Kršćanska sadašnjost, Zagreb, 2017., 469. O Ježiću vidi Hrvatski biografski leksikon (on-line izdanje), s.v. „Ivan Krstitelj Ježić“, http:// hbl.lzmk.hr/clanak.aspx?id=8654 [skinuto 15. travnja 2015.]

44 Kapitanović, Hrvatska crkva, 151-152.

45 Vrhovac, Dneunik, 387, 469, 479 i 510.

46 Télégraphe Officiel, br. 44, 3. lipnja 1813., 179. 
Ovaj primjer „građanskoga neposluha“ tim više izaziva čuđenje jer je Banija pratio glas pristaše Francuza koji se javno zakleo na vjernost francuskoj vlasti i okružnicom o novačenju u francusku vojsku izazvao opoziciju kod dubrovačkoga klera. ${ }^{47}$ Prema svemu sudeći, puno je toga ovisilo o stavu civilne uprave i o njezinu odnosu s crkvenim predstavnicima. Njih je pogotovo u Dalmaciji, na kvarnerskim otocima i u dubrovačkom području bilo izrazito puno. Državnu upravu opterećivala je komunikacija i pregovaranje s velikim brojem vjerskih dužnosnika, ${ }^{48}$ što je onemogućavalo brzo provođenje reformi kao na sjeveru.

\section{ZAKLJUČAK}

Konkordatom iz 1801. godine Napoleon je otvorio novo poglavlje u povijesti Katoličke Crkve i države u kojem je naizgled izvršena pomirba između načela Francuske revolucije i Crkve. Sljedeće godine Napoleon je dao proglasiti tzv. „Organičke članke“ kojima su katolički nauk i liturgija stavljeni pod državnu kontrolu. U ceremoniji Napoleonove samokrunidbe (sacre) u crkvi Notre Dame 2. prosinca 1804. godine. vladarska je moć prikazana kao iznad papinske moći jer se Napoleon sam okrunio i nije bilo ceremonije prostiranja pred papom Pijom VII. Ta je ceremonija trebala poslužila širenju propagande Napoleonova imperijalnoga kulta koji je za cilj imao prvenstveno usađivanje lojalnosti podanika prema Napoleonovoj osobi. U propagandističkom smislu posebna je uloga bila dodijeljena Katekizmu za sve katoličke crkve u Francuskom Carstvu, poznatom kao Carski katekizam. Ondje je pouci četvrte Božje zapovijedi bio pridodan dodatak u kojem je bio spomenut izričito sam Napoleon i njegova dinastija, kojima su vjernici dužni iskazivati lojalnost i žrtvu, što je predstavljalo presedan u dotadašnjoj katekizamskoj tradiciji.

47 Ante Dračevac, „Nikola Ban (Bani)“, Hrvatski biografski leksikon, http://hbl. lzmk.hr/clanak.aspx?id=1209 [skinuto 26. rujna 2019.]. Dana 8. listopada 1810. godine 69 svećenika predvođeni Banijem položilo je prisegu vjernosti caru Napoleonu. Njih šesnaestorica, među kojima je bilo uglednih dominikanaca i franjevaca, odbilo je prisegnuti, pa su bili pritvoreni, a neki su pobjegli u emigraciju. Stjepan Ćosić, Dubrovnik nakon pada Republike (1808.-1848.), Zavod za povijesne znanosti HAZU, 1999., 84.

48 Ideja generalnog intendanta Ilirskih pokrajina Christopha de Chabrola (1771. 1836., intendant od 16. kolovoza 1811. do kolovoza 1813.) da se u Iliriji trebaju poklapati civilno i crkveno ustrojstvo, tj. da ono treba obuhvaćati samo dvije nadbiskupije i šest biskupija, nije bila provedena jer za provedbu nije bilo vremena. Kapitanović, Hrvatska crkva, 153. 
S obzirom na ovu novinu i naglasak na moralu umjesto na kršćanskim dogmama, ovaj katekizam nije odobrio papa, pa je ulogu odobravatelja preuzeo „jakobinski“ kardinal Caprara, smatran nekom vrstom otpadnika od Rimske stolice. Carski ukaz i Caprarino odobrenje nalazili su se na početku svakoga izdanja Carskoga katekizma, što je ukazivalo da je njegovo uvođenje bio najprije čin civilne vlasti, pa tek onda crkvene. Katekizam je doživio izdanja na više europskih jezika, a njegovo prevođenje bio je žurni projekt svake francuske uprave, pa tako i one u Dalmaciji i Ilirskim pokrajinama, čiju je kronologiju trebalo strpljivo rekonstruirati iz različitih vrela. I Dandolo i Marmont kao revni upravitelji nastojali su pronaći prevoditelje Carskoga katekizma na „ilirski“, tj. hrvatski jezik, koji su se već iskazali u prevodilačkoj praksi. Međutim, to se pokazalo kao veliki problem zbog nepostojanja standardiziranoga književnoga jezika, a i nedostatka izdavačke tradicije koja bi poticala prevođenje kao praksu. Osim toga, domaćim prevoditeljima iz svećeničkoga staleža nije mogla lako pasti uloga prevoditelja tekovina Napoleonova imperijalnoga kulta i njegova transfera u jedan kulturno-ideološki posve drugačiji kontekst, u kojem su postojale mnoge konfliktne situacije i dileme oko opozicije i/ili kolaboracije s francuskim vlastima. Vremena za postizanje prave recepcije zapravo nije bilo: prijevodni pokušaji ostaju nam tek kao materijalni podsjetnici o nastojanjima kratkotrajne francuske uprave da uvede kakvo-takvo nacionalnograđansko jedinstvo na periferiji Francuskoga Carstva. (završetak)

\section{PRILOZI}

1.

Catéchisme de toutes les églises catholiques de l'Empire française, imprimé par ordre de Son A. E. M.gr le Cardinal FESCH, Archevêque de Lyon, Vienne et Embrun, Primat des Gaules, etc. A l'usage de son Diocèse, Rusand, Lyon, 1806., 89-91.

LEKCIJA (POUKA) VII. * Nastavak iste [četvrte] zapovijedi:

PITANJE: Koje su dužnosti kršćana prema prinčevima koji njima vladaju, i koje su posebno naše dužnosti prema Napoleonu I., našem caru?

ODGOVOR: Kršćani duguju prinčevima koji njima vladaju, i mi posebno dugujemo Napoleonu I., našem caru, ljubav, poštovanje, poslušnost, vjernost, vojnu službu, i poreze koji se ubiru za zaštitu i obranu carstva i njegova prijestolja; također mu dugujemo vruće molitve za njegovo zdravlje te za duhovno i temporalno blagostanje države. 
PITANJE: Zašto podliježemo svim ovim dužnostima prema caru?

ODGOVOR: Prvo, zato što je Bog, koji je stvorio carstva i rasporedio ih prema svojoj volji, time što je našega cara opskrbio darovima i u miru i u ratu, ustanovio ga kao našeg vladara i učinio ga izvršiteljem svoje moći i svoje slike na zemlji. Častiti i služiti našem caru stoga znači častiti i služiti samoga Boga.

Drugo, zato što nas je naš sam Gospodin Isus Krist i preko svoga učenja i svojim primjerom poučavao što dugujemo našem vladaru. Čak i pri samom svom rođenju poslušao je ukaz Cezara Augusta: plaćao je ustanovljeni porez, i dok nam je naredio da Bogu damo one stvari koje pripadaju Bogu, također nam je naredio da Cezaru dajemo one stvari koje su Cezarove.

PITANJE: Postoje li posebni motivi koji bi nas bliže povezali s Napoleonom I., našim carem?

ODGOVOR: Da, zato što je Njega Bog podigao u vremenima kušnje da ponovno uspostavi javno bogoslužje svete vjere naših otaca i da bude njezin zaštitnik; on je ponovno uspostavio i očuvao javni red svojom dubokom i aktivnom mudrošću; on brani državu svojom moćnom rukom; on je postao Gospodinov pomazanik posvećenjem koje je primio od papinskoga suverena, poglavara univerzalne Crkve.

PITANJE: Što nam je misliti o onima koji su nemarni u svojim dužnostima prema našem caru?

ODGOVOR: Prema apostolu Pavlu, oni se odupiru redu koji je uspostavio sam Bog i čine da zavređuju vječnu osudu.

PITANJE: Vežu li nas dužnosti koje imamo prema svome caru jednako i prema njegovim legitimnim nasljednicima, prema redu kako nalažu ustavi carstva?

ODGOVOR: Da, izvan svake sumnje; jer čitamo u Svetom Pismu da Bog, gospodar neba i zemlje, prema raspoloženju svoje najviše volje i svojom providnošću daruje carstva ne samo jednoj osobi već i njegovoj obitelji.

PITANJE: Koje su naše obveze prema drugim dužnosnicima?

ODGOVOR: Moramo ih častiti, poštivati i slušati; jer su oni vršitelji vlasti našega cara.

PITANJE: Što nam se zabranjuje četvrtom zapovijedi?

ODGOVOR: Zabranjeno nam je biti neposlušni prema našim pretpostavljenima, štetiti im i govoriti o njima loše.

Prevela s francuskoga jezika: dr. sc. Teodora Shek Brnardić 
2.

Katechismus u svih Francuskog cesarstva cirkvah uselan. U Karlovzu 1812. Czivil, y Militarzkom Knyg Pritiskanyu, 3-4.

U Dvoru Tulerien 4. Aprila 1806.

NAPOLEON

Cesar Francuski, Kralj Italianski.

Na objavljenje nashega ministra cerkovni posala jesmo zapovidili i zapovidamo $z$-ovim

I. Art. za izpunienie 39.toga articula zakona od 18 germinal desetoga litta ovome decretu priklopljeni kathekismus od Njih Zvisnosti cardinala legata [Caprare] zaprijetan imase kroz slovotisk ocsito na znanje dati, i samo po njemu jedinom u svih katolicsanskih Cesarstva cirkvah ladatise.

II. Art. Nash minister cerkovni posala ima ovog kathekismusa slovotisk preskerbiti, i on je sve k-tomu potribne priprave ucsiniti kroz deset godina osobite uvlastjen.

III. Art. Isti ovai decret imase u svakog katechisma prilicie uslovotisnut, i u nashih zakonov buletin postaviti.

IV. Art. Nashemu cerkovni posala ministru nalaxese ovai isti decret u zvershenost dopeljati.

Podpisat Hugues B. Maret Matici jednakoglasno minister cerkovni posala podpisat Portalis

THE TRANSLATIONS OF NAPOLEON'S CATECHISM (1806) IN DALMATIA AND THE ILLYRIAN PROVINCES, PART TWO

\section{Summary}

With the coming to power in the Croatian lands the French administration tried to enforce the French state legislation. Among other things, this included the Concordat of 1801 between Napoleon and the Holy See, and Napoleon's unilateral law supplement in the form of 77 "Organic Articles "entered into force in the same year. These documents made the Catholic dioeceses in France a kind of imperial administrative bodies supervised by the Ministry of Cult. The article 39 prescribed from then on the existance of only 
one liturgy and only one catechism in all the Catholic churces of the French Empire. This was the foundation for the composition of one universal Catechism for all the Catholic Churches in the French Empire, known as the Imperial Catechism and published in 1806. The state authorities introduced it without the approval of Pope Pius VII. For the first time in the history of catechisms, a secular name was explicitly mentioned wih the lesson about the Fourth God's Commandement. To be sure, it was the name of Emperor Napoleon I. In 1807, Vincenzo Dandolo, general governer of Dalmatia, was the first to order the translation of the Imperial Catechism into the "Illyrian ", that is, Croatian language because Dalmatia became a part of the Kingdom of Italy. This attempt failed because of reviews, which pointed to the bad intelligibility of the translation for the ordinary people. In the Illyrian Provinces founded in 1809, the translations in Italian, Slovenian, German and "Illyrian "or Croatian were either integrally or partly (just a couple of chapters), published at the incentive of civil authorities in 1811 and 1812. They remained without an impact because the Provinces were abolished already in 1813 and Napoleon's catechism was strictly forbidden by Austrian authorities. Nevertheless, these translation ventures remain very valuable examples of propaganda and the attempt of cultural transfer of Napoleon's imperial cult into these regions, which will be discussed in this paper.

Key words: Imperial Catechism, Napoleonic religion, religious education, cultural transfer, cultural imperialism 